Karol Kowalczuk*

Uniwersytet w Białymstoku

https://orcid.org/0000-0002-4275-3372

\title{
Biblioteka jako miejsce kształtowania kompetencji kluczowych w dobie technologii cyfrowych
}

Streszczenie: Rozwój społeczeństwa informacyjnego wpłynął na funkcjonowanie wielu obszarów współczesnego życia. Stał się silnym determinantem przeobrażeń w działalności ośrodków administracyjnych, ale także kultury i nauki. Funkcjonowanie w czasie płynnej nowoczesności determinuje także zupełnie inne ujęcie roli, jaką przypisuje się bibliotekom. Coraz częściej mówi się o wirtualnym lub multimedialnym ich charakterze dostosowanym do odbiorców posiadających zróżnicowane kompetencje w przetwarzaniu cyfrowych danych. Jest to szczególnie istotne w świecie, gdzie obok cyfrowych imigrantów funkcjonują cyfrowi tubylcy.

Słowa-klucze: cyfrowa biblioteka, kompetencje cyfrowe, multimedia.

\section{Library as a place to shape key competences in the digital era}

Summary: The development of the information society has affected the functioning of many areas of modern life. This process became a strong determinant of transformations in the activities of administrative centers,

* Karol Kowalczuk - dr, adiunkt w Zakładzie Dydaktyki Ogólnej Wydziału Nauk o Edukacji Uniwersytetu w Białymstoku; autor m.in. książki Edukacja w pikselach. Gry komputerowe w procesie kształcenia (2016) oraz współredaktor monografii naukowych: $W$ kierunku edukacji akademickiej zorientowanej na studenta (2016), Innowacje w perspektywie jakości kształcenia (2019). 
but also of culture and science. Functioning at the time of fluctuating modernity also determines a completely different view of the role assigned to libraries. More often than not they are referred to as having virtual or multimedia character that is adjusted to recipients exhibiting different competencies of digital data processing.. This is particularly important in a world where digital natives function alongside digital immigrants.

Key words: digital library, digital competences, multimedia.

Wiele instytucji przestrzeni publicznej wraz z rozwojem społeczeństwa informacyjnego ewoluuje, modyfikując swoje statutowe funkcje. Przyczyniają się do tego bardzo dynamiczne zmiany w obszarze przetwarzania danych, które są silnym determinantem przeobrażeń w funkcjonowaniu obszarów administracyjnych. Dotykają one instytucji kultury i placówek edukacyjnych. Szkoły dokonują niezbędnych reform systemu nauczania-uczenia się, dostosowując treści i metody do wymogów stawianych przez współczesną dydaktykę. Obejmują one zarówno wymagania kreowane przez rozwój społeczeństwa, jak również indywidulane potrzeby edukacyjne uczniów. Dotyczy to zagadnień, które skupiają się wokół określonej strategii dydaktycznej, której zadaniem jest przekazanie informacji w najbardziej atrakcyjny dla współczesnego ucznia sposób. W równie dużym stopniu zachodzące zmiany dotykają także placówek przestrzeni publicznej - w szczególności biblioteki.

Rola, jaką przypisuje się bibliotekom w przestrzeni społecznej, również ulega dynamicznym zmianom, a co za tym idzie, ewoluują oczekiwania odbiorców wobec tej instytucji. Klasyczne ujęcie biblioteki, określanej jako placówka, której głównym zadaniem jest katalogowanie i gromadzenie zawartości księgozbiorów, a także udostępnianie ich użytkownikom ${ }^{1}$ wydaje się w dzisiejszych czasach nie tyle nieadekwatne, co bardzo uproszczone. Funkcjonowanie społeczeństwa w czasie płynnej nowoczesności determinuje zupełnie inne ujęcie jej funkcji.

1 W. Okoń, Nowy słownik pedagogiczny, Warszawa 2001, s. 42. 
W związku z tym głównym założeniem funkcjonowania bibliotek jest transmisja prawie wszystkich możliwych treści, a także ukierunkowanie na obsługę wszystkich potencjalnych klientów, którzy wyrażą chęć bycia jej użytkownikami². Ze względu na fakt, iż nierozerwalnie odbywa się to w przestrzeni publicznej, której uczestnicy posiadają określone preferencje, coraz częściej możemy mówić o wirtualnym lub cyfrowym charakterze biblioteki ${ }^{3}$.

Takie podejście stanowi kompleksowe ukazanie nie tylko kluczowych kierunków przypisanych funkcjonowaniu instytucji kultury, ale także wskazuje na zmiany, które wydają się konieczne w obliczu coraz szerszego funkcjonowania człowieka w cyfrowej przestrzeni społecznej. Znaczenie bibliotek w obecnych czasach wcale nie ulega zmarginalizowaniu, wręcz przeciwnie, są one szczególnie ważne w czasach cyfrowych, jak i przedcyfrowych. Ich rola jednak się zmienia - muszą wyjść naprzeciw oczekiwaniom współczesnego społeczeństwa informacyjnego oraz zagwarantować szereg cyfrowych usług, kluczowych dla sprawnego funkcjonowania człowieka XXI wieku4.

Elementem, który stał się kluczowym determinantem szerokich zmian społecznych w ujęciu holistycznym, było pojawianie się Internetu. W Polsce upowszechnienie się sieci rozpoczęło się w latach 90. XX wieku i trwa do dnia dzisiejszego. Możliwości korzystania z Internetu w początkowym okresie były nader ubogie i dostępne nielicznym tylko instytucjom. $Z$ czasem sieć zaczęła być bardziej popularna, ale ograniczenia technologiczne związane z małą przepustowością łączy internetowych (opartych głównie na łączach telefonicznych) oraz duże koszty eksploatacji w znaczący sposób ograniczały powszechność dostępu. Pod koniec lat 90. ubiegłego stulecia i na początku XXI wieku w przestrzeni publicznej pojawily się tzw. kafejki internetowe, które w znacznym stopniu zaspokajały potrzebę szerokiego dostępu do informacji. Nowy wiek przyniósł jednak rewolucję technologiczną, czego skutkiem było stworzenie ogólnodostępnej sieci internetowej. Zmieniło to nie tylko sposób dostępu do informacji, ale przede wszystkim sposób jej dystrybucji. Powstanie

2 J. Wojciechowski, Obszary wiedzy o bibliotekarstwie, Warszawa 2017, s. 172.

3 A. Tokarska, Biblioteka w przestrzeni informacyjnej, [w:] Bibliotekarstwo, red. A. Tokarska, Warszawa 2013, s. 23-25.

4 B. Lison, The New Role of Public Libraries in Local Communities, https://research4committees.blog/2017/12/13/the-new-role-of-public-libraries-in-local-communities/ [dostęp: 25.04.2019 r.]. 
Google - czyli wyszukiwarki, która jednocześnie stała się wyznacznikiem nowego standardu dostępu danych, a także Wikipedii, czyli serwisu determinującego powstanie filozofii Web 2.0 zdecydowanie i nieodwracalnie zmieniło sposób pozyskiwania, przetwarzania i dzielenia się informacją. Miało to swoje konsekwencje we wszystkich sferach życia człowieka. Nie bez znaczenia było to również dla funkcjonowania bibliotek, które dostosowując się do potrzeb rynku, rozszerzyły swoją działalność, zachowując jednocześnie własną autonomię.

\section{Różne strategie odbioru informacji}

Rewolucja cyfrowa i wykorzystanie sieci jako dominującego sposobu pozyskiwania informacji diametralnie zmieniły sposób myślenia różnych pokoleń w społeczeństwie. Problem ten w kontekście edukacyjnym, wyjątkowo trafnie nakreślił Marc Prenscy5. Ukazał on współczesną strukturę edukacyjną, w obrębie której musi nastąpić proces komunikacji dwóch wzajemnie zależnych od siebie grup, wykorzystujących jednak zupełnie odmienne systemy analizy i przetwarzania treści. Wyróżnił on cyfrowych imigrantów - osoby urodzone w epoce przedcyfrowej wykorzysujące analogowy system przetwarzania danych - a także cyfrowych tubylców, czyli osoby urodzone w świecie mediów cyfrowych, które przetwarzają informacje w sposób zdigitalizowany, preferując wielokanałowość. Różnice w sposobie analizy danych rodzą liczne konflikty w kontekście procesu nauczania-uczenia się, ponieważ w klasie lekcyjnej spotykają się dwie grupy zmuszone poniekąd do wzajemnej koegzystencji, ale wykorzystujące zupełnie przeciwstawne strategie komunikacyjne i transmisji danych. Cyfrowi imigranci - nauczyciele - skupiają się zazwyczaj na jednym kanale (analogowo), a ich uczniowie - cyfrowi tubylcy, preferują podejście bardziej rozproszone - wielokanałowe (cyfrowe).

Z perspektywy czasu teoria ta traci powoli na aktualności, ponieważ pierwsze pokolenia cyfrowych tubylców już dorosły i weszły na rynek pracy. W konsekwencji zaś różnice między tymi dwiema grupami i generowane przez nie problemy bardzo powoli, ale nieustannie zanikają. Następuje przesunięcie wyraźnej granicy między dominującymi strategiami analizy informacji będące następstwem dorastania młodych pokoleń. System dostępu do danych

5 M. Prensky, Digital Natives, Digital Immigrants, „On the Horizon” 2001, t. 9, nr 5. 
oparty na podejściu dynamicznym, wielokanałowym i powierzchniowym staje się najbardziej atrakcyjnym z punktu widzenia młodego odbiorcy. Jest to bezpośrednim następstwem dominacji Internetu jako głównego źródła dostępu do danych. Sieć tworzy przestrzeń wszechstronnego, ale także wielokanałowego dostępu opartego na współpracy niemal wszystkich zmysłów: wzroku, słuchu, dotyku (obsługa myszki i klawiatury), a do tego w formie przestrzennej, jaką stwarza hipertekstowy charakter informacji umieszczanych w sieci. Powszechność tego źródła niesie jednak ze sobą negatywne konsekwencje w postaci przesilenia informacyjnego oraz bardzo pobieżnej analizy treści.

Pomimo faktu, iż dominującym sposobem przetwarzania danych wśród osób starszych jest nadal system jednokanałowy, nie ulega wątpliwości, iż rozumieją one potrzebę zmiany obowiązującego paradygmatu w pozyskiwaniu i przetwarzaniu informacji.

\section{Różne potrzeby społeczne}

O ile problem przekazu danych między cyfrowymi uczniami i analogowymi nauczycielami w przestrzeni edukacyjnej rozwiązuje się poprzez zastosowanie metod, środków i narzędzi dydaktycznych opartych na elementach cyfrowych, o tyle w publicznej przestrzeni biblioteki problem ten nabiera zupełnie innego wymiaru. Powodem tego jest fakt, iż nie dominuje w tym przypadku konflikt komunikacyjny, ale bardziej dylemat, w jaki sposób dostosować strategię dystrybucji informacji do zróżnicowanych grup odbiorców. Oczywiście problem ten możemy rozpatrywać poprzez pryzmat potrzeb indywidualnych, które w określonym stopniu zaspokajają podział na wypożyczalnie dla dorosłych i dzieci, lub podział tematyczny księgozbiorów. Nabiera on jednak zupełnie innego wymiaru, jeżeli rozpatrujemy go nie w kontekście określonej tematycznie grupy, ale poprzez pryzmat umiejętności czy wręcz predyspozycji indywidualnych odbiorców. Nie da się zaadoptować podejścia zastosowanego w edukacji, gdyż problemem nie jest konieczność dostosowania działań jednej grupy do oczekiwań drugiej (nauczyciele i uczniowie), lecz konieczność stworzenia takiej przestrzeni, gdzie każdy odbiorca informacji będzie mógł wykorzystać preferowaną przez siebie strategię.

Zróżnicowane grupy odbiorców wymagają indywidualnego podejścia i generują potrzebę organizowania strategii wychodzących naprzeciw ich oczekiwaniom. Biblioteka należy do instytucji, które skupiają w znacznym stopniu 
społeczność lokalną, ale podejmowane przez nie inicjatywy mogą obejmować różne grupy użytkowników z bardzo zróżnicowanego otoczenia ${ }^{6}$. Do inicjatyw najbardziej charakterystycznych dla bibliotek można zaliczyć:

$\checkmark$ transkrypcję;

> katalogowanie, kategoryzowanie, kontekstualizację;

- kolaboratywne tagowanie i linkowanie;

- generowanie treści;

$\checkmark$ nadawanie georeferencji;

- komentowanie, opiniowanie, rekomendowanie;

- społecznościowe pozyskiwanie funduszy?

Powyższe elementy świadczą o holistycznym ujmowaniu funkcjonowania biblioteki. Wśród nich muszą znaleźć się inicjatywy i strategie, które są atrakcyjne z punktu widzenia zróżnicowanego odbiorcy.

Rozwój technologiczny, a w jego rezultacie nowoczesne środki przekazu generujące nowe obszary przetwarzania treści, a także służące do komunikowania się, leżą u podstaw nowych możliwości, jakie stoją przed bibliotekami. Media społecznościowe, wirtualność, hipertekstowość pozwalają na skuteczną promocję i budowę atrakcyjnego wizerunku, ale także na dotarcie do nowych grup odbiorców ${ }^{8}$.

$\mathrm{W}$ ten sposób biblioteki wpisują się także w proces funkcjonowania w świecie mediów społecznościowych. Jego założeniem jest ich obecność w przestrzeni wirtualnej dzięki wykorzystaniu różnych kanałów informacyjnych. Można ją rozpatrywać przez pryzmat sprzężenia zwrotnego na linii bibliotekarz - użytkownik, jak również w kontekście aktywnego rozwijania i kreowania internetowych społeczności. Taki punkt widzenia może leżeć u podstaw nowego definiowania przestrzeni biblioteki określanej mianem 2.0, która zakłada współpracę między bibliotekarzem oraz obecnymi, a także przyszłymi użytkownikami, umożliwiając im partycypację w kreowaniu środowiska. Daje to szansę na organizowanie, dystrybuowanie, ocenianie i komunikowanie się między wszystkimi podmiotami uczestniczącymi w życiu bibliotek. Możliwości, jakie daje

6 M. Curyło, Czytelnik jako prosument - niebezpieczeństwo czy ratunek dla bibliotek, [w:] Multibibliotekartswo, red. M. Wojciechowska, Warszawa 2018, s. 80.

7 Tamże.

8 A. Koszowska, Nowe media $w$ bibliotece, [w:] Bibliotekarstwo, dz. cyt., s. 429. 
szerokie wykorzystanie Internetu, a przez to również mediów społecznościowych, przekłada się na łatwość przystosowania i gotowość do ciągłych zmian9. W świecie płynnej nowoczesności jest to nie bez znaczenia, zwłaszcza w kontekście zróżnicowanych oczekiwań określonych grup odbiorców.

Bez wątpienia szerokie wykorzystanie potencjału cyfrowych narzędzi powoduje, iż przestrzeń publiczna nabiera bardziej adekwatnego i przyjaznego charakteru dla młodego pokolenia wychowanego w czasach cyfrowych. Nie inaczej jest z bibliotekami, które również bazują na hipertekstualności Internetu, ale w sposób bardzo przemyślany wykorzystują jego potencjał do kreowania nowej, atrakcyjnej przestrzeni pozyskiwania informacji. Dzięki temu młodzi odbiorcy przyzwyczajeni do cyfrowego świata funkcjonują w obszarze, który nie jest wyjęty z ich przestrzeni życiowej. $Z$ całą pewnością są to zabiegi, które mają zachęcić, zwłaszcza uczniów wywodzących się z pokolenia cyfrowego, do aktywnego uczestnictwa w życiu biblioteki. Ta aktywność rozpatrywana jest w kategoriach celów związanych z realizacją zadań wynikających z obowiązku szkolnego, ale także z uczestnictwem w obrębie ich czasu wolnego. Pierwsza może ograniczać się do opracowania lektur lub zagadnień z zakresu określonych dydaktyk szczegółowych i posiada znamiona raczej tradycyjnego uczestnictwa. Przybierać może ona postać korzystania z zasobów cyfrowych w formie audiobooków lub bazując na dostępnych stacjach komputerowych wykorzystania Internetu w celu opracowania zagadnienia. Druga kategoria korzystania może być związana z realizacją własnych zainteresowań w czasie wolnym. Funkcjonowanie młodego człowieka w tej kategorii ma zdecydowanie odmienny charakter, ponieważ cechuje je dobrowolność podejmowanych czynności oraz przyjemność towarzysząca tym zajęciom. Cechuje go również duża swoboda oraz względnie nieformalny charakter działań. Czas wolny powinno się rozpatrywać $\mathrm{w}$ ujęciu holistycznym jako ten, który może być poświęcony wielostronnemu rozwojowi na miarę szans i wyzwań stawianych przed człowiekiem funkcjonującym w cywilizacji informacyjnej ${ }^{10}$.

Biblioteka z całą pewnością pozwala na realizację powyższych celów. Szeroki dostęp do księgozbiorów, a także możliwość wykorzystania zbiorów zdigitalizowanych oraz bezpośredniego dostępu do Internetu, poszerza ofertę

10 K. Denek, Poza ławką szkolna, Poznań 2002, s. 74. 
instytucji i stawia ją w świetle bardzo atrakcyjnym dla odbiorcy, którego koegzystencja opiera się na silnej korelacji świata realnego i wirtualnego.

Drugą grupą użytkowników bibliotek, należącą do grupy cyfrowych imigrantów, są osoby dorosłe, które wychowały się na tradycyjnych książkach i analogowych źródłach przekazu informacji. Biblioteka w klasycznym ujęciu jest dla nich obszarem naturalnym, ponieważ od zawsze jej księgozbiór był traktowany jako pierwsze i naturalne źródło zdobywania i poszerzania wiedzy. Jednak ewolucja cyfrowa, a w związku z tym i zmiana filozofii sytemu dostępu i dystrybucji treści spowodowały, iż skupienie się jedynie na pozyskiwaniu informacji - w ujęciu klasycznym - może stanowić duże ograniczenie płynności funkcjonowania odbiorcy w przestrzeni społecznej.

Brak kompetencji z zakresu korzystania $\mathrm{z}$ technologii informacyjno-komunikacyjnych w coraz bardziej cyfrowym społeczeństwie stanowić może nie tylko całkowite wyłączenie z funkcjonowania w przestrzeni publicznej, ale także ograniczenie swobody dostępu do jego szerokiego potencjału. W dobie przenoszenia wielu usług do przestrzeni wirtualnej (np. sektor usług bankowych, sektory szeroko rozumianej administracji publicznej) posiadanie znikomych lub wręcz zerowych umiejętności informatycznych w dużej mierze stanowi ograniczenie płynności funkcjonowania. Wymusza to również konieczność korzystania z tradycyjnych form, które związane są jednak z ograniczeniami czasowymi i zdecydowanie mniejszą efektywnością.

W związku z tym cyfrowość, która w bibliotece jest cechą atrakcyjną dla młodego odbiorcy, staje się również bardzo istotną wartością dla osób starszych. Ze względu na publiczny charakter, biblioteka jako placówka lokalna jest także miejscem, gdzie bardzo często cyfrowi imigranci spotykają się z cyfrowym przekazem.

Zagrożenie e-wykluczeniem, które obejmuje starszych użytkowników bibliotek, jest szczególnie niebezpieczne w kontekście ogólnej ewolucji cywilizacyjnej. Może być następstwem braku motywacji i potrzeby korzystania z Internetu, obawy przed nowymi technologiami, braku umiejętności korzystania z sieci, niewystarczającej wiedzy o możliwościach oferowanych przez sieć, albo wręcz przekonania o ich bezużyteczności ${ }^{11}$. Obok konieczności dostosowania przekazu do preferencji młodych odbiorców to właśnie zagroże-

11 A. Koszowska, dz. cyt., s. 429. 
nie cyfrowym wykluczeniem stanowi jeden z czynników, który jest kluczowy w procesie rozszerzania dotychczasowej oferty bibliotek o zakres usług $\mathrm{z}$ obszaru integracji digitalnej ${ }^{12}$. Wpłynęło to $\mathrm{w}$ stopniu istotnym nie tylko na bogactwo świadczonych usług, ale przede wszystkim na sam charakter funkcjonowania placówki. Oba wyzwania wyznaczyły tym samym nowe zadania, z którymi pracownicy musza się zmierzyć, ale również dało szerokie możliwości podejmowania innowacyjnych rozwiązań.

Konieczność dostosowania formy przekazu do zróżnicowanych odbiorców i ich potrzeb powoduje, że w bibliotekach pojawia się szeroka oferta edukacyjna skierowana do zróżnicowanej grupy użytkowników. Jest to podejście oczekiwane, gdyż sceptycyzm w stosunku do nowych technologii, a przez to również do możliwości, jakie ze sobą niosą, może stanowić przyczynę marginalizacji bibliotek w przestrzeni społecznej ${ }^{13}$.

Oferta skierowana do grup odbiorców o różnych potrzebach będzie generowała zróżnicowane strategie jej realizacji. Do cyfrowych tubylców powinny być skierowane elementy bazujące na nowych technologiach, ukazujące adekwatność prezentowanych zagadnień w stosunku do wirtualnej przestrzeni, w której dzieci i młodzież funkcjonują na co dzień. Możemy mówić tu o strategii podtrzymującej. W odniesieniu do użytkowników starszych, wywodzących się z pokolenia cyfrowych imigrantów, dominującymi powinny być strategie wprowadzające lub utrwalające. Czyli te, które będą polegały głównie na wprowadzeniu nowych umiejętności i podtrzymaniu zdobytych kompetencji na określonym poziomie.

Do licznych form edukacyjnych wykorzystujących potencjał nowych technologii skierowanych do starszych odbiorców możemy zaliczyć: kursy i szkolenia komputerowe, spotkania wprowadzające uczestników w świat nowoczesnych technologii oraz popularyzujące ich zastosowanie, a także doradztwo konsultacyjne i pomoc w obsłudze sprzętu komputerowego ${ }^{14}$. W obrębie tych zadań mogą znaleźć się szkolenia z zakresu podstaw obsługi komputera, wyszukiwania informacji, obsługi pakietów biurowych (edytorów tekstu arkuszy kalkulacyjnych, programów prezentacyjnych), programów do obróbki grafiki

12 Tamże.

13 J. Wojciechowski, dz. cyt., s. 143.

14 A. Koszowska, dz. cyt., s. 429. 
i zdjęć, programów umożliwiających komunikację internetową za pośrednictwem komunikatorów i portali społecznościowych lub programów sprecyzowanych tematycznie (np. z zakresu finansów w Internecie lub bezpieczeństwa w sieci).

W obrębie działań skierowanych do młodych odbiorców również mogą być prowadzone szkolenia ukierunkowane na osiągniecie podobnych założeń, jednak bazujące na posiadanych już cyfrowych kompetencjach. Często są one zdecydowanie bardziej specjalistyczne i uszczegółowione oraz ukierunkowane na realizację ściśle określonych celów. Mogą to być szkolenia z obszaru modyfikacji grafiki komputerowej, montażu filmów i muzyki, efektywnego wykorzystania potencjału sieci, a także, cieszące się ostatnio dużym zainteresowaniem, programowania lub robotyki.

Efektywna realizacja wymienionych form podnoszenia kompetencji cyfrowych wynika z aktywizacji samych użytkowników bibliotek, ale w dużej mierze osiągnięcie zamierzonych rezultatów jest możliwe tylko dzięki wysokim predyspozycjom i cechom osobowym samych bibliotekarzy.

\section{Kompetencje wspólczesnego bibliotekarza}

Konieczność dostosowania się do zróżnicowanych grup odbiorców wymagających zdecydowanie innej strategii współpracy, a także posługiwanie się nowymi technologiami stanowi dla pracowników bibliotek duże wyzwanie. Efektem tego jest konieczność posiadania przez kadrę szerokich kompetencji nie tylko merytorycznych, ale także metodycznych. Ze względu na przestrzeń, w której są podejmowane zadania, zakres świadczonych usług oraz samych użytkowników, kompetencje bibliotekarzy zdecydowanie mieszczą się w szeroko ujmowanym Systemie Zarządzania Kompetencyjnego. Możemy w nim wyróżnić:

- kompetencje społeczne, które odnoszą się do jakości relacji, odpowiadają za skuteczność współpracy, obopólny kontakt, a także wywieranie wpływu na innych;

- kompetencje osobiste, które określają wpływ na jakość wykonywanych zadań, a także zaangażowanie w podejmowane działania;

• kompetencje menadżerskie i przywódcze związane z organizacją, decydujące o skuteczności zarządzania pracą oraz obejmujące jej organizację i strategiczny aspekt zarządzania; 
- kompetencje zawodowe związane ze specjalistycznymi zadaniami dla danej grupy zawodowej, odnoszące się do określonych obszarów sprecyzowanej wiedzy lub konkretnych umiejętności (np. obsługa określonych systemów IT), których poziom wpływa na efektywność realizacji zadań ${ }^{15}$.

Tak szerokie zestawienie predyspozycji bibliotekarza jest szczególnie istotne w przypadku pracowników placówek bibliotecznych podejmujących prace w obszarze technologii cyfrowych. Odpowiednie relacje ze społecznością lokalną (w zakresie kompetencji społecznych) stanowią silny fundament skuteczności podejmowanych działań, ponieważ to dzięki nim możliwe staje się prawidłowe uargumentowanie konieczności wdrażania różnych form doskonalenia cyfrowego. Ze względu na określoną grupę odbiorców podejście to będzie przybierało inną postać. W przypadku cyfrowych imigrantów ważniejsze będzie odpowiednie zmotywowanie konieczności podejmowania nowych form kształcenia ustawicznego, a w przypadku młodych odbiorców bardziej odpowiednie wydaje się uzmysłowienie konieczności zdobywania wysokich cyfrowych kompetycji. Praca z tak różnymi grupami odbiorców, ale przede wszystkim współpraca z osobami, które czują się niepewnie w środowisku cyfrowym, może wiązać się ze skrajnymi reakcjami na ich postępy w nauce - od frustracji i zniechęcenia po zapał i zadowolenie. Od dobrze ukształtowanych kompetencji osobowych bibliotekarza zależy jak skutecznie będzie potrafił on zmotywować uczestników szkoleń czy warsztatów do dalszej pracy. Realizacja kursu wymaga także umiejętności menadżerskich związanych z całościową organizacją i kompleksowym zespoleniem wszystkich elementów wchodzących w skład podejmowanego działania, począwszy od przygotowania pracowni na wyborze odpowiedniego oprogramowania kończąc. Oczywiście żadne z podjętych działań mających na celu podnoszenie kwalifikacji cyfrowych w określonej grupie odbiorców nie może być zrealizowane bez odpowiednich kompetencji zawodowych pracowników określających ich merytoryczne i metodyczne przygotowanie do podejmowanych wyzwań.

W dobie płynnej nowoczesności technologie informacyjne stają się determinantem zmian w wielu obszarach przestrzeni społecznej. Umiejętne wykorzystanie ich potencjału przekłada się często na osiągnięcie sukcesu w wielu

15 Uniwersalny Model Kompetencyjny. Podręcznik użytkownika, https://docplayer. pl/1816641-Uniwersalny-model-kompetencyjny.html, [dostęp 25.04.2019 r.]. 
sferach związanych z podejmowanymi obowiązkami zawodowymi. Znacząca rola technologii cyfrowych zmienia także sposób i charakter funkcjonowania dużej liczby placówek publicznych - w tym także bibliotek. To przede wszystkim one od zawsze umożliwiały i stanowiły determinant rozwoju społeczności lokalnej. W dobie cyfrowej rewolucji ich znaczenie nie zmniejsza się, a wręcz przeciwnie - stanowią one bardzo ważne ogniwo łączące człowieka z nowymi technologiami. Dotyczy to zarówno osób, które posiadają podstawową wiedzę z zakresu obsługi cyfrowych narzędzi, jak również tych, których umiejętności cyfrowe plasują się na wysokim poziomie.

\section{Bibliografia}

Bibliotekarstwo, Nauka - Dydaktyka - Praktyka, red. A. Tokarska, Warszawa 2013.

Curyło M., Czytelnik jako prosument - niebezpieczeństwo czy ratunek dla bibliotek, [w:] Multibibliotekartswo, red. M. Wojciechowska, Warszawa 2018.

Denek K., Poza ławką szkolną, Poznań 2002.

Koszowska A., Nowe media w bibliotece, [w:] Bibliotekarstwo, Nauka - Dydaktyka Praktyka, red. A. Tokarska, Warszawa 2013.

Lison B., The New Role of Public Libraries in Local Communities, https://research4committees.blog/2017/12/13/the-new-role-of-public-libraries-in-localcommunities/, [dostęp: 25.04.2019 r.].

Multibibliotekartswo, red. M. Wojciechowska, Warszawa 2018.

Okoń W., Nowy słownik pedagogiczny, Warszawa 2001.

Prensky M., Digital natives, digital immigrants, „On the Horizon” 2001, t. 9, nr 6, s. 1-6.

Uniwersalny Model Kompetencyjny. Podręcznik użytkownika, https://docplayer. pl/1816641-Uniwersalny-model-kompetencyjny.html, [dostęp: 25.04 .2019 r.].

Wojciechowski J., Obszary wiedzy o bibliotekarstwie, Wydawnictwo Stowarzyszenia Bibliotekarzy Polskich, Warszawa 2017. 